\title{
Analysis of cutting forces during in-cut and out-cut milling of EN AC-AISi10Mg cast aluminum alloy
}

\author{
Analiza sił skrawania przy frezowaniu współbieżnym \\ i przeciwbieżnym odlewniczego stopu aluminium EN AC-AISi10Mg
}

\author{
JÓZEF KUCZMASZEWSKI \\ PAWEK PIEŚKO \\ MAGDALENA ZAWADA-MICHAŁOWSKA *
}

The analysis of cutting forces during in-cut and out-cut milling of EN AC-AISi10Mg cast aluminum alloy was presented. The research included measurement of the components of the total cutting force: $F_{f}, F_{p}$ and $F_{c}\left(F_{x}, F_{y}, F_{z}\right.$ respectively) and determination of their amplitudes at a constant feed per tooth value and the adopted variable technological parameters, i.e.: depth of cut $a_{p}$, milling width $a_{e}$ and cutting speed $v_{c}$. Based on the obtained results, it was found that along with the increase in the depth of cut and the milling width, the values of selected components and their amplitudes increase for both in-cut and out-cut milling. During rise of cutting speed, it was observed that the components of the total cutting force increase to the speed $v_{c}=450 \mathrm{~m} / \mathrm{min}$, then their values begin to decrease. This is related to the transition from conventional machining to the range of High Speed Cutting. It is important that higher values of cutting forces were noted in the case of out-cut milling instead of incut milling.

KEYWORDS: milling, cutting forces, aluminium alloy, technological parameters.

Milling is a dynamically developing machining method. Due to the kinematics of the process, it is divided into [3, 7 , 8]:

- out-cut milling (fig. 1a) - the directions of the tangential speed of the milling cutter and the workpiece advance are the opposite,

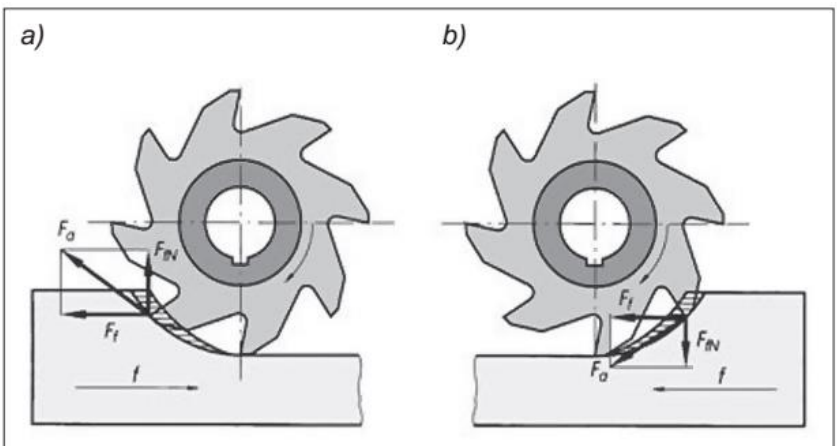

Fig. 1. Milling: a) out-cut, b) in-cut [3, 7]

\footnotetext{
* Prof. dr hab. inż. Józef Kuczmaszewski (j.kuczmaszewski@pollub.pl), dr inż. Paweł Pieśko (p.piesko@pollub.pl), mgr inż. Magdalena ZawadaMichałowska (m.michalowska@pollub.pl) - Katedra Podstaw Inżynierii Produkcji, Wydział Mechaniczny Politechniki Lubelskiej
}

- in-cut milling (fig. 1b) - directions of tangential milling current and workpiece feed are in line.

During out-cut milling (fig. 1a) the cutting layer at the beginning of penetration of the blade into the material increases from zero and finally reaches the maximum. This results in the fact that the cutting resistance is the smallest when the cutting edge starts and the largest - when it is finished. However, it should be emphasized that during outcut milling, the cutting edge is used more quickly, because the friction process is intensified, which also causes deterioration of the treated surface compared to in-cut milling. A negative phenomenon is the accumulation of chips that form during the process, which plug the grooves and significantly hinder cooling $[3,7,8]$.

In the case of in-cut milling (fig.1b), the cut layer is the thickest at the beginning of the blade work, then it decreases. The same is with cutting resistance. In addition, there is no friction of the cutting edge to the machined surface before machining. The tool life and efficiency of the process is therefore longer. The quality of obtained surfaces is also better due to the easier removal of chips from the machining zone $[3,7,8]$.

Machining is a complex physical process during which many phenomena occur, such as [2-5, 8]:

- stress formation causing elastic and plastic deformations, - internal friction in the deformed material layers and external friction between the chips and the rake surface, as well as the flank surface with the workpiece,

- generation and propagation of heat, which changes the properties of the workpiece and to some extent also the tools,

- wear of the blade, resulting in a change in its working conditions.

These phenomena are closely interrelated and interact with each other. However, their examination is much more difficult, including due to high temperature $[2,4,5]$.

For each working surface of the blade involved in the cutting process, forces are the result of pressure (normal force) and friction (tangential force). The total cutting force $F$ is spatially located, causes separation of the material allowance, overcomes its cohesion forces and frictional resistances between the tool, the material and the chip, under specific machining conditions. It is the resultant of three constituent vectors acting along the lines determined by the reference system (machine tool-object-tool) $[3,4,7]$ : 


$$
\bar{F}=\bar{F}_{c}+\bar{F}_{f}+\bar{F}_{p}
$$

where: $F_{\mathrm{c}}$ - peripheral component; $F_{\mathrm{f}}$ - feed component; $F_{\mathrm{p}}$ resistance component.

Value of the cutting force depends on many factors, including cross-sectional areas of the cutting layer and mechanical properties of the material being processed, therefore it can be varied over a wide range $[1,6,8]$.

\section{Research methodology}

The purpose of the work was to determine the effect of in-cut and out-cut milling of the aluminum alloy EN ACAISi10Mg on the cutting forces and their amplitudes. The chemical composition of the alloy is shown in the tab. I. It is widely used in castings characterized by complex shapes and high strength.

TABLE I. Chemical composition of EN AC-AISi10Mg alloy

\begin{tabular}{|c|c|c|c|c|c|c|c|c|c|c|}
\hline \multicolumn{10}{|c|}{ Elements contents, \% } \\
\hline $\mathbf{S i}$ & $\mathbf{C u}$ & $\mathbf{M g}$ & $\mathbf{M n}$ & $\mathbf{C r}$ & $\mathbf{F e}$ & $\mathbf{T i}$ & $\mathbf{Z n}$ & $\mathbf{N i}$ & $\mathbf{P b}$ & $\mathbf{A l}$ \\
\hline 10 & $\leq$ & 0,33 & $\leq$ & $\leq 0,1$ & $\leq$ & $\leq$ & $\leq 0$, & $\leq$ & $\leq$ & $\begin{array}{c}\text { Remain- } \\
\text { ing }\end{array}$ \\
\hline
\end{tabular}

The milling of cuboidal samples was carried out on the Avia VMC $800 \mathrm{HS}$ vertical machining center. Six carbide two-edged shaft cutters $\varnothing 12 \mathrm{~mm}$ from Sandvik (symbol: R216.32-12030-AC22A H10F) were used. During the tests, the wear status of the cutting blades was monitored.

The stand for measuring the components of cutting forces consisted of:

- Kistler piezoelectric dynamometer 9257B,

- four-channel load amplifier,

- DAQ module with built-in A/D card,

- specialized software that allows data acquisition and analysis.

First of all, the measurements of the cutting forces $F_{\mathrm{x}}\left(F_{\mathrm{f}}\right)$, $F_{\mathrm{y}}\left(F_{\mathrm{p}}\right)$ and $F_{\mathrm{z}}\left(F_{\mathrm{c}}\right)$ for in-cut and out-cut milling were carried out. The following technological parameters have been selected: milling width $a_{\mathrm{e}}=2 \mathrm{~mm}$, feedrate $f_{\mathrm{z}}=0.025$ $\mathrm{mm} / \mathrm{blade}$, speed $n=8000 \mathrm{rpm}$ and resulting cutting speed $v_{\mathrm{c}}=301 \mathrm{~m} / \mathrm{min}$ and six different depths of cut (tab. II). The highest 10 force values were selected from the range and the average was calculated.

In the second part of the experiment, three components of the total cutting force were also measured, assuming variable milling width as parameters, while the constant parameters were: cutting depth $a_{p}=2 \mathrm{~mm}$, feed per tooth $f_{z}$ $=0.025 \mathrm{~mm} /$ blade and speed $n=8000 \mathrm{rpm}$ (tab. III).

TABLE II. Technological parameters - the first part of the experiment

\begin{tabular}{|c|c|c|}
\hline $\begin{array}{c}\text { No. of } \\
\text { sample }\end{array}$ & $\begin{array}{c}\text { Variable parameter: } \\
\text { cutting depth } a_{\mathrm{p}}, \mathrm{mm}\end{array}$ & $\begin{array}{c}\text { Constant parameters: feed per blade, } \\
\text { milling width, rotational speed }\end{array}$ \\
\hline $\mathbf{1}$ & 2 & \\
\hline 2 & 4 & \multirow{2}{*}{$\begin{array}{c} \\
\text { feed } f_{\mathrm{z}}=0,025 \mathrm{~mm} / \mathrm{blade} \\
\text { milling width } a_{\mathrm{e}}=2 \mathrm{~mm} \\
\text { rotational speed } \mathrm{n}=8000 \mathrm{rpm}\end{array}$} \\
\hline 3 & 6 & \\
\hline 5 & 10 & \\
\hline 6 & 12 & \\
\hline
\end{tabular}

TABLE III. Technological parameters - the second part of the experiment

\begin{tabular}{|c|c|c|}
\hline $\begin{array}{l}\text { No. of } \\
\text { sample }\end{array}$ & $\begin{array}{l}\text { Variable parameter: } \\
\text { cutting depth } a_{e}, \mathrm{~mm}\end{array}$ & $\begin{array}{l}\text { Constant parameters: feed per blade, } \\
\text { milling width, rotational speed }\end{array}$ \\
\hline 1 & 2 & \multirow{6}{*}{$\begin{array}{l}\text { feed } f_{2}=0,025 \mathrm{~mm} / \mathrm{blade} \\
\text { Depth of cut } a_{0}=2 \mathrm{~mm} \\
\text { rotational speed } n=8000 \mathrm{rpm}\end{array}$} \\
\hline 2 & 4 & \\
\hline 3 & 6 & \\
\hline 4 & 8 & \\
\hline 5 & 10 & \\
\hline 6 & 12 & \\
\hline
\end{tabular}

The third stage of the research involved measurement of the component cutting forces for five cutting speeds $v_{\mathrm{c}}=$ $151 ; 301 ; 454 ; 754$ and $904 \mathrm{~m} / \mathrm{min}$, with constant parameters, i.e.: milling width $a_{\mathrm{e}}=2 \mathrm{~mm}$, feedrate $f_{\mathrm{z}}=0.025$ $\mathrm{mm} / \mathrm{blade}$ and depth of cut $a_{\mathrm{p}}=2 \mathrm{~mm}$.

\section{Results}

The components of cutting forces $F_{\mathrm{x}}\left(F_{\mathrm{f}}\right), F_{\mathrm{y}}\left(F_{\mathrm{p}}\right)$ and $F_{\mathrm{z}}$ $\left(F_{\mathrm{c}}\right)$ as well as their amplitudes in in-cut and out-cut milling were analyzed as a function of time.

Fig. 2 shows exemplary cutting forces: milling width $a_{\mathrm{e}}=$ $2 \mathrm{~mm}$, feedrate $t_{z}=0.025 \mathrm{~mm} /$ edge and cutting depth $a_{p}=$ $10 \mathrm{~mm}$ for out-cut milling (fig. 2a) and in-cut milling (fig. $2 \mathrm{~b}$ ). It is worth noting that with the same technological parameters, the range of force variation $F_{z}$ is clearly smaller for in-cut milling. This machining variant is therefore more advantageous in terms of process stability.

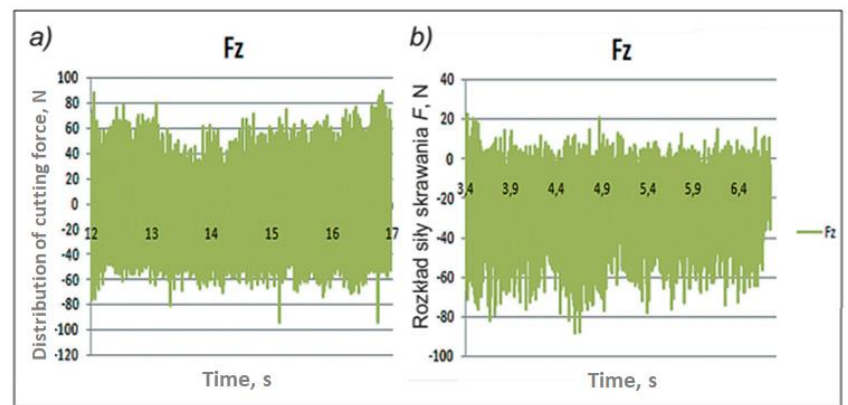

Fig. 2. Exemplary runs of the cutting force component $F_{z}$ for milling: a) out-cut, b) in-cut

Considering the distribution of all constituent forces $F_{\mathrm{x}}$ $\left(F_{\mathrm{f}}\right), F_{\mathrm{y}}\left(F_{\mathrm{p}}\right)$ and $F_{\mathrm{z}}\left(F_{\mathrm{c}}\right)$ obtained with a constant milling width $a_{\mathrm{e}}=2 \mathrm{~mm}$ and variable cutting depth, it was noted that the highest values were recorded for force $F_{\mathrm{y}}$, and the smallest for $F_{\mathrm{z}}$.

Fig. 3 shows the characteristic of the cutting force component $F_{y}$ and its amplitude as a function of depth of cut. On the basis of the obtained results, it was noticed that as the depth of cut increases, the value of the $F_{y}$ force component increases for both in-cut and out-cut milling. The amplitude of the force also increases as the depth of cut increases. It is important that the higher values of the cutting force component $F_{\mathrm{y}}$ and its amplitude were obtained for outcut milling. 


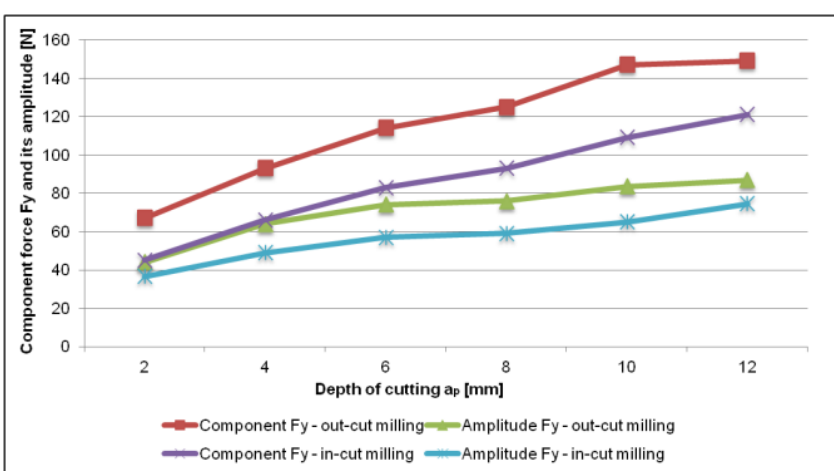

Fig. 3. Characteristics of the cutting force component $F_{y}$ and its amplitude as a function of the milling depth $a_{p}$ for in-cut and out-cut milling

On the basis of the analysis of the measurement results of the cutting forces $F_{\mathrm{x}}\left(F_{\mathrm{f}}\right), F_{\mathrm{y}}\left(F_{\mathrm{p}}\right)$ and $F_{\mathrm{z}}\left(F_{\mathrm{c}}\right)$ obtained at constant depth of cut $a_{\mathrm{p}}=2 \mathrm{~mm}$ and variable milling width $\mathrm{ae}$, the largest values were noted for the $F_{\mathrm{x}}$ component, and the smallest - for the $F_{\mathrm{z}}$ component.

Fig. 4 shows the values of the selected component of the cutting force $F_{x}$ and its amplitude as a function of the milling width. Based on the obtained results, it was found that the value of the cutting force component $F_{\mathrm{x}}$ and its amplitude increase along with the increase of the milling width both in the in-cut and the out-cut milling. Also in this case, higher values were recorded for out-cut milling.

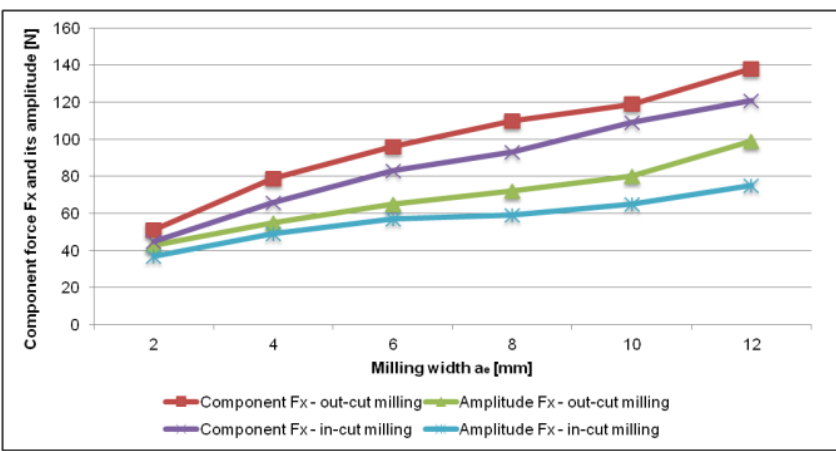

Fig. 4. Characteristic of the cutting force component $F_{x}$ and its amplitude as a function of the milling width $a_{e}$ for in-cut and out-cut milling

At the last stage of the research, the influence of the cutting speed on the value of the component of the cutting force $F_{y}$ and its amplitude was analyzed. Fig. 5 presents the characteristic of the cutting force component Fy and its amplitude as a function of the cutting speed for in-cut and out-cut milling. When the cutting speed increases, the force increases to reach the maximum at a speed of approx. $v_{\mathrm{c}}=$ $450 \mathrm{~m} / \mathrm{min}$, then decreases. The values obtained for in-cut milling are lower than for out-cut milling.

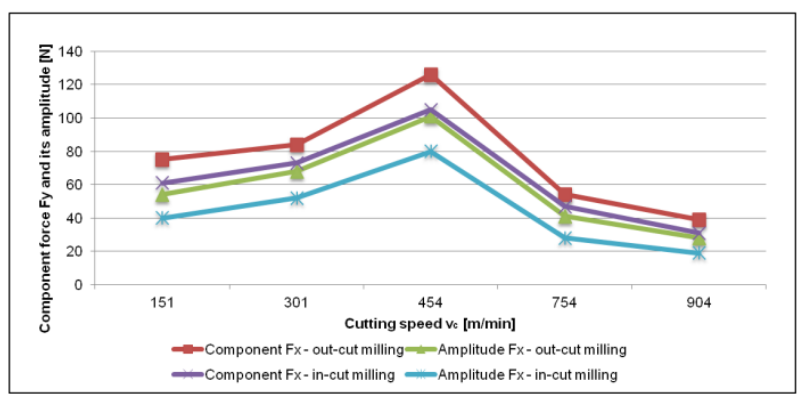

Fig. 5. Characteristic of the cutting force component $F_{y}$ and its amplitude as a function of the cutting speed $v_{c}$ for in-cut and out-cut milling

Similar relations were found for the remaining components of cutting forces at all analyzed variables.

\section{Conclusions}

Based on the research described, the following conclusions were made:

- The amplitude of the cutting forces is one of the measures of the stability of the machining process. It can be concluded that in-cut milling is more advantageous in terms of process dynamics.

- For the cutting depth variable for both in-cut and out-cut milling, it was noticed that the highest values were recorded for the $F_{\mathrm{y}}$ component and the smallest for $F_{z}$.

- With the variable milling width, the largest values were noted for the $F_{\mathrm{x}}$ component, and the smallest - also for $F_{\mathrm{z}}$, for both in-cut and out-cut milling.

- Values of selected constituent forces and their amplitudes increase with increasing depth of cut and milling width, both for in-cut and out-cut milling.

- For a milling width of more than $6 \mathrm{~mm}$, i.e. more than $50 \%$ of the cutter diameter, the ratio of the amplitude of the force to its value decreases. This means that you can increase machining efficiency by increasing the milling width with a relatively small change in machining stability.

- When increasing the cutting speed, the force $F_{y}$ increases and reaches the maximum at a speed of approx. $V_{\mathrm{c}}=450 \mathrm{~m} / \mathrm{min}$, then its value decreases.

\section{REFERENCES}

1. Bławucki S., Matuszak J., Zaleski K. „Badania sił skrawania podczas frezowania superstopu Inconel $718 \mathrm{z}$ podwyższoną

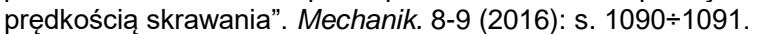

2. Baohai W., Xue Y., Ming L., Ge G. „Cutting force prediction for circular end milling process". Chinese Journal of Aeronautics. 26, 4 (2013): pp. $1057 \div 1063$.

3. Dul-Korzyńska B. „Obróbka skrawaniem i narzędzia”. Rzeszów: Oficyna Wydawnicza Politechniki Rzeszowskiej, 2009.

4. Jemielniak K. „Obróbka skrawaniem”. Warszawa: Oficyna Wydawnicza Politechniki Warszawskiej, 2004.

5. Kuczmaszewski J., Zagórski I. „Badania sił skrawania i ich amplitud podczas frezowania stopów magnezu”. Postępy Nauki i

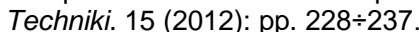

6. Małkiński J., Siemiński P. „Badanie wpływu szerokości skrawania i prędkością posuwu na wartość sił skrawania podczas frezowa-

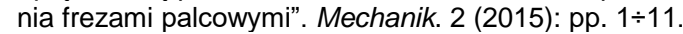

7. Olszak W. „Obróbka skrawaniem”. Warszawa: WNT, 2009.

8. Drozd K. „Analiza sił skrawania przy frezowaniu współbieżnym i przeciwbieżnym frezami trzpieniowymi”. Praca magisterska. Promotor: prof. dr hab. inż. J. Kuczmaszewski. Lublin: Politechnika Lubelska, 2011.

Translation of scientific articles, their computer composition and publishing them on the website www.mechanik.media.pl by original articles in Polish is a task financed from the funds of the Ministry of Science and Higher Education designated for dissemination of science.

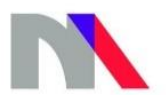

Ministry of Science and Higher Education Republic of Poland 